\title{
Professional objectives of higher education: imbalances and adaptation
}

\author{
Elena Konstantinovna Voronkova ${ }^{1}$ and Mariya Vladimirovna Dolgova \\ Plekhanov Russian University of Economics, Finance and Prices Department, Moscow, Russia
}

\begin{abstract}
This article analyzes the systemic issues of personnel education in higher education, reveals their causes and consequences. Qualitative and quantitative characteristics of university graduates are one of the conditions for the state economic development. The goals and objectives of higher education should meet the needs of the state, industries, regions, and business. The lack of strong signals from consumers of educational services creates an imbalance between the higher education system and the market requirements and results in the conservatism of higher education. In this context, the purpose of this article is to develop a conceptual model for assessing the contribution of higher education to the national economy as one of the drivers of its transformation. The need to optimize the professional structure of education, with reference to the potential and prospects of the national economy, is emphasized. Research methods involve analysis and synthesis, induction and deduction, system and logical methods. The study result is a model that takes into account a number of indicators of employer satisfaction in university graduates, as well as indicators of regional and industrial security of specific professionals with higher education. An effective motivation for employers to take a more active part in the organization of higher education is the system of educational loans. The state's management of the credit sphere creates opportunities for consumers of educational services to direct financial flows primarily to education in priority specialties. The effectiveness of this tool requires ensuring its accessibility to employers and differentiating interest rates.
\end{abstract}

Keywords: higher education, professional education, financing

\section{Introduction}

Higher education (HE) is the climax of professional education of specialists, and it should correspond as closely as possible to national strategies. This is possible if the goal of managing the higher education system is to form appropriate schemes for the interaction of the provision and the consumption levels of educational services [1, 2].

Educational processes in society have a fundamental impact on the national economy [3]. There is a direct correlation between the qualitative and quantitative education characteristics and the indicators of the state economic development. The number of

${ }^{1}$ Corresponding author: Voronkova.EK@rea.ru 
students and graduates, the structure of graduates by specialties and territories are among the indicators of such influence, etc. In turn, the effectiveness of higher education is strongly determined by state targets [4].

The number of students in the Russian higher education institutions is gradually decreasing. The number of students studying under contracts for the provision of paid educational services is increasing, mainly at the expense of state and municipal institutions of higher education, despite a significant increase in the cost of education in this group of institutions. State and municipal higher education institutions steadily remain on the top in terms of the number of students, but the number of students receiving education at the expense of budget allocations is decreasing. These trends were especially significant after 2010 (Table 1).

Table 1. Dynamics of indicators of the higher education development in the Russian Federation. Source: compiled by the authors based on the materials of the statistical digest "Education in numbers" [https://www.hse.ru/primarydata/oc/].

\begin{tabular}{|l|c|c|c|c|c|c|}
\hline \multicolumn{1}{|c|}{ Indicator } & \multicolumn{5}{c|}{ Years } \\
\cline { 2 - 7 } & 2000 & 2005 & 2010 & 2017 & 2018 & 2019 \\
\hline $\begin{array}{l}\text { 1. The rate of change in average consumer prices } \\
\text { for education per term in higher education } \\
\text { institutions: }\end{array}$ & & & & & & \\
\hline private & & & & & & \\
\hline in state and municipal & 1.00 & 1.82 & 2.77 & 5.69 & 6.18 & 6.96 \\
\hline $\begin{array}{l}\text { 2. The rate of change in the number of students (at } \\
\text { the beginning of the academic year) }\end{array}$ & 1.00 & 2.28 & 3.63 & 8.20 & 9.71 & 10.62 \\
\hline including at the expense of: & & & 1.49 & 0.90 & 0.88 & 0.86 \\
\hline budget allocations & 1.00 & 1.07 & 0.94 & 0.68 & 0.68 & 0.68 \\
\hline $\begin{array}{l}\text { under contracts for the provision of paid } \\
\text { educational services in institutions, } \\
\text { including }\end{array}$ & 1.00 & 2.09 & 2.28 & 1.21 & 1.16 & 1.12 \\
\hline state and municipal & & & & & & \\
\hline private & 1.00 & 2.03 & 2.20 & 1.3 & 1.28 & 1.26 \\
\hline $\begin{array}{l}\text { 3. The share of students studying in state and } \\
\text { municipal educational institutions, \% } \\
\text { including }\end{array}$ & 90.29 & 84.72 & 82.96 & 90.04 & 90.88 & 91.84 \\
\hline $\begin{array}{l}\text { under contracts for the provision of paid } \\
\text { educational services }\end{array}$ & 73.43 & 72.69 & 72.90 & 82.19 & 83.45 & 85.07 \\
\hline $\begin{array}{l}\text { 4. The share of students in state and municipal } \\
\text { educational institutions studying under contracts } \\
\text { for the provision of paid educational services, \% }\end{array}$ & 34.39 & 49.83 & 55.22 & 50.34 & 49.64 & 49.60 \\
\hline
\end{tabular}

In recent years, the professional demand has gradually changed in favor of such technical specialties as engineering, technology, and technical sciences. At the same time, the number of graduates in economics and management is decreasing, although this area of education remains among the leading. The structure of professional education in higher education is shown in Fig. 1. 


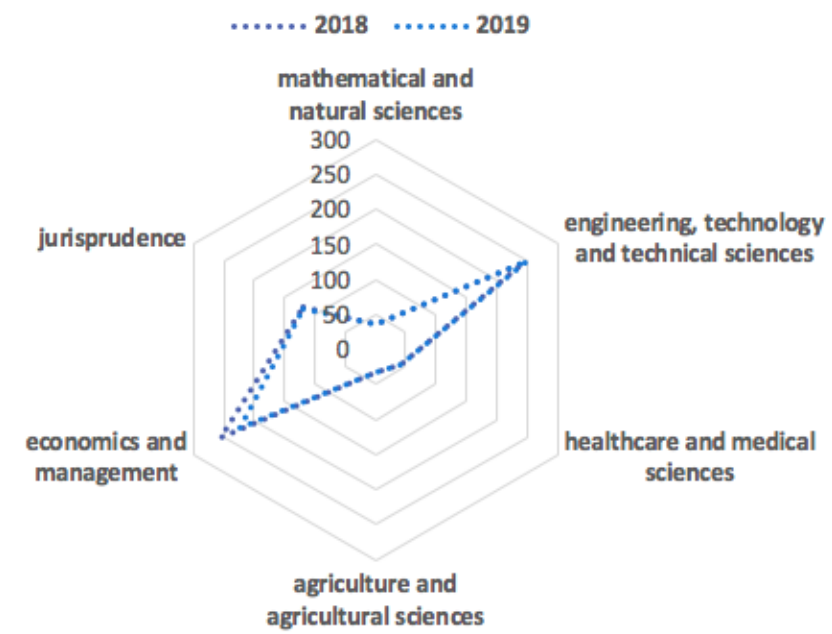

Fig. 1. Structure of professional education in higher education, the number of graduates, thousand people. Source: compiled by the authors based on the materials of the statistical digest "Education in numbers" [5].

\section{$2 \quad$ Materials and method}

The purpose of this work is the presentation of the author's view of promising models for assessing the contribution of the higher education to the national economy, as one of the incentives for its transformation. The research methodology is based on the principles of scientific objectivity and a systematic approach. It is based on general scientific methods, such as analysis and synthesis, induction and deduction, system and logical methods. This study uses official regulatory documents, statistical and analytical reviews to identify current trends in the higher education development, the features of its financing. Extensive factual database of state and international institutional structures has facilitated the reliability of the scientific provisions of this study.

\section{$3 \quad$ Results}

The current state of higher education in the Russian Federation represents some connection with the market requirements [6]. Thus, due to the development of the banking sector, trade, foreign trade, active integration processes, professions related to finance, commerce, and law became particularly popular at a certain historical stage. Today, there is an increased demand for technical professions. As was previously noted, the higher education institutions enhance the education of specialists in this area. At the same time, there is obvious conservatism and inertia in the organization of the higher education system according to the structure of professional personnel education.

Higher education should have such features as flexibility, the ability to quickly and adequately adapt to modern realities. The severe conditions of the Russian modern development require the creation and implementation of a higher education model, which would make it possible to "pinpoint" the imbalances in the interaction of higher education and the market [3]. At the same time, the higher education specialties should, first of all, attract by the demand for the market rather than by the unusual "names". This requires 
increasing the role of employers representing both the state and corporate levels. Their task is to form an understanding among consumers and sellers of educational services in the society interest in specific professions and specialties. Otherwise, the market of educational services will increasingly break away from the economy realities. It is fair to say, that having obvious difficulties with finding professionals in some areas, employers weakly give a warning of such problems to higher education.

Insufficient involvement of employers in the forming a professional structure in higher education appropriate for the market results in failures in education in certain professional areas. Already today, there is a shortage of some specialties due to the fact that universities have stopped such education due to a lack of applicants' interest. Thus, now we do not educate specialists in pricing, but they were greatly educated in the number of leading universities until the mid-90s. During the period of economic reforms, during the transition from a planned to a market economy, the point of view prevailed that only the market will determine prices and, therefore, education of these specialists is not relevant. Pricing began to be considered, first of all, as one of the marketing directions and the corresponding disciplines were excluded from the curricula of the vast majority of economic specialties, and education of specialists in pricing was terminated.

The consequences of this decision are currently a severe shortage of highly qualified specialists in state structures and companies who are able to comprehensively analyze the relationships in the economy at the macro, meso and micro levels, to identify the influence of various (at first glance, unrelated) factors on specific prices and pricing processes. Belated and ambiguous decisions related to keeping the prices for socially important products under control, the processes of forming and determining price dynamics - this result was particularly pronounced this year. Business needs pricing specialists who possess a wide range of competencies and skills, as evidenced by the data from the websites of recruiting companies. At the same time, the difference between the minimum and maximum salaries offered to "price makers" in the country is tenfold, in Moscow fourfold, which indicates, among other things, a very different level of professionality of specialists employed in this field.

In recent years, a number of professional standards for pricing specialists have been developed and approved, as well as professional standards that include specific labor functions for pricing. Their introduction has resulted in an explosive increase in demand for seminars and advanced training courses on pricing, especially in construction and procurement. A similar pattern was after the entry into force in 2012 of changes in the Tax Code of the Russian Federation concerning transfer pricing.

A number of top universities have scientific schools and experienced personnel to educate specialists in pricing. But potential employers do not set specific tasks for higher education about the education of bachelors and masters of the appropriate profile, are not ready to accept students for industrial and pre-graduate internships, as well as conclude agreements on targeted financing or preferential lending to students. Thus, employers, experiencing the need for personnel in certain specialties, do not send clear requests to the higher education system for their education.

It is possible to eliminate the described imbalance and promote the activities of employers in the HE system through the financing system. The development of conditions and financing schemes for Russian higher education is constant [7]. However, the most important moment problem of the state is to optimize the processes of allocating financial resources in accordance with consumer demand, which is supported both by applicants and employers [8]. It is necessary to strengthen professional specifics more strongly when developing state programs of financial support for higher education. For example, a group 
of higher education institutions is financed by a "blend pool", not identifying critical points of expenditure of funds allocated by the state, even within the framework of the strategic Project 5-100, aimed at maximizing the competitive position of top Russian universities in the global market of educational services and research programs [9].

In our opinion, as priorities when making managerial decisions concerning the financing of higher education, it is necessary to take into account the long-term consequences of the higher education quality in the national economy. Its key guideline should be the degree of satisfaction of employers' interests detailed by profession: more than just economists, but specialists in prices or corporate finance, etc. [10]. At the same time, regional and sectoral monitoring of business satisfaction is particularly important for our country.

So here is a task to develop a model for assessing the contribution of higher education to the national economy, turning it into a key reference point when choosing a professional orientation at the higher education level $[11,12]$. Traditional approaches to this assessment are based mainly on GDP growth rates and the level of wages. The latter indicator, as for the authors, quite logically reflects the degree of the economy interest in workers with higher education. But it is only if the ratio of wages of qualified and unskilled labor is appropriate $[13,14]$, taking into account the importance of a particular specialty for the national market. It is necessary to exclude such situations typical for modern times when the average salary of a driver in Saint Petersburg is a quarter higher than that of an engineer, which the domestic economy lacks, or 10\% higher than that of a doctor [15].

In the integral assessment of the contribution of higher education to the economy, there should be indicators of the detailed level of employers' satisfaction in the needed professions in general, as well as indicators of regional and industrial security in higher education graduates in the professional context.

$$
K_{H E C}=\{B 1, B 2, B 3\}
$$

where $K_{H E C}$ - integral indicator of the contribution of higher education to the national economy;

$B 1,2, \ldots \ldots n$ - relevant indicators that characterize the degree of satisfaction of employers, regions and industries in specialists with higher education by profession. If necessary, each element of the formula can be argued depending on the significance of the indicator, which may change with changes in the state of the economy.

\section{Discussion}

Finally, the system of educational credit should become a real motivation for employers to pay more attention to the organization of educational processes in higher education. The state manages this sphere, allowing consumers of HE services to realize their desires, thus directing financial flows to universities. An educational loan should be considered as a fine-tuning tool that adapts to the market situation, primarily the domestic market. There is a need for this in the Russian Federation. For example, the step to reduce interest rates on educational loans in 2020 was very timely. However, it is necessary to further promote the dynamics of educational credit, including in the context of the problem of attracting employers to renovate the scheme of higher professional education.

Educational loans make it possible to find the right way to structure the system of higher professional education. For this purpose, firstly, it is possible to differentiate the interest rates on educational loans depending on the specific specialization of higher education, depending on the requests of employers, which will increase the motivation of 
the entire "employer-university-applicant" bundle. Secondly, it is necessary to manage the availability of employers to an educational loan in order to provide financial support for the future specialists of the company, now students, paying for their education and providing regular living conditions. Then universities, receiving additional funding from employers for education in certain specialties, will be more willing to switch to educating students "on request". The differentiation principle of interest rates on an educational loan can also work in this case, for example, depending on the complexity of the educational process or the level of the profession scarcity.

It should be noted that the practice of financing education, guaranteeing a workplace and a certain level of income after graduation by the future employer of a student in the higher education system should become wider. This is extremely important, especially for emerging markets. The analysis of the relevant indicators on the EAEU market shows the direct dependence of personal expenses for higher education on the real disposable income of the population in a vast majority of the EAEU member states [16]. Otherwise, if the disposable real income of the population falls, the plans for educating specialists that employers rely on may be disrupted $[17,18]$.

\section{Conclusion}

Thus, the study shows that the balance of interests of all participants in the process of educating specialists in the Russian higher education system can be ensured only with an increase in the role of employers, professional adaptation of educating to territorial and industrial peculiarities, and management decisions on the scale and cost of paid education should become more flexible from the position of social orientation.

Renovation of approaches to the formation of the professional structure of personnel education in the higher education system, involving the strengthening of the employer role, will increase both the competitiveness of the higher education system itself and the national economy as a whole, the efficiency of public and private spending on higher education, the degree of satisfaction of needs in the education market.

\section{References}

1. F.J. Altbach, Global perspectives of higher education, A. Ryabova (ed) (Ed. house of the Higher school. Economics, Moscow, 2018). https://doi.org/10.17323/978-5-7598-1712-3

2. H. Hall, Econ Law, 17(1), 33-42 (2018). https://doi.org/10.12775/EiP.2018.003

3. A. Hamdan, A. Sarea, R. Khamis, M. Anasweh, Heliyon, 6, e04046 (2020). https://doi.org/10.1016/j.heliyon.2020.e04046

4. E.E. Lehman, M. Meoli, S. Paleari et al., Eurasian Bus Rev, 8(1), 37-54 (2017). https://doi.org/10.1007/s40821-017-0091-7

5. Education in Figures. Accessed on: September 25, 2021. [Online]. Available: https://www.hse.ru/en/primarydata/oc/

6. L.V. Ávila, et al., J Cleaner Prod, 164, 1268-1278 (2017).

https://doi.org/10.1016/j.jclepro.2017.07.025

7. T.N. Sedash, E.A. Kameneva, Rus Foreign Econ J, 5, 50-58 (2021). https://doi.org/10.24411/2072-8042-2021-5-50-58 
8. O.P. Ovchinnikova, N.E. Ovchinnikova, Fin Credit, 23(38), 2305-2316 (2017). https://doi.org/10.24891/fc.23.38.2305

9. Project 5-100. Accessed on: September 25, 2021. [Online]. Available:

https://5top100.ru/documents/regulations/97332/

10. E.K. Voronkova, M.V. Dolgova, Edu. Sci. Sci Pers, 4, 197-200 (2020). https://doi.org/10.24411/2073-3305-2020-10239

11. E.Ya. Kogan, N.Yu. Postalyuk, T.G. Kuteinitsyna, Higher Edu Rus, 28(7), 9-18 (2019). https://doi.org/10.31992/0869-3617-2019-28-7-9-18

12. B. Stensaker, J.J. Lee, G. Rhoades, S. Ghosh, et al., J Higher Edu, 90(4), 539-562 (2019). https://doi.org/10.1080/002215 46.2018.1513306

13. B.S. Potanin, Stud Rus Econ Devel, 30(3), 319-326 (2019).

https://doi.org/10.1134/S1075700719030146

14. E.V. Romanov, The Edu Sci J, 21(9), 9-48 (2019). https://doi.org/10.17853/1994-5639-2019-9-9-48

15. Statistika zarplat v Rossii [Salary statistics in Russia]. https://gorodrabot.ru/salary?l=\%D1\%80\%D0\%BE\%D1\%81\%D1\%81\%D0\%B8\%D1\% $8 \mathrm{~F}$

16. Obrazovanie $\mathrm{v}$ tsifrakh [Education in Figures].

http://www.eurasiancommission.org/ru/act/integr_i_makroec/dep_stat/econstat/Docum ents/Education\%20Yearbook/EducationEAEU2020.pdf

17. X. Sheng, British J Soc Edu, 38(5), 721-737 (2017). https://doi.org/10.1080/01425692.2016.1158638

18. M. Shnarbekova, Rus Edu Soc, 60(4), 70-380 (2018). https://doi.org/10.1080/10609393.2018.1473700 